\title{
EVALUASI IMPLEMENTASI PENILAIAN PENDIDIKAN OLEH PENDIDIK PADA PEMBELAJARANTEKNIK KOMPUTER DAN JARINGAN DI SMKN I NEGERIKATON - LAMPUNG
}

\author{
Agus Wahyudi \\ Universitas Negeri \\ Jakarta
}

\section{Komarudin}

Universitas Negeri Jakarta

\section{Awaluddin Tjalla Universitas Negeri Jakarta}

\begin{abstract}
The purpose of this evaluation study is to determine the level of successful implementation of assessment standards conducted by educators on productive subjects Computer and Network Engineering (TKJ) in SMKN I Negerikaton Lampung Province using Model Discrepancy Evaluation Model (DEM). Methods of data collection are done through interviews, observation, document studies and questionnaires. This study focuses on assessments made by educators who are components of research principles, assessment forms, assessment mechanisms, assessment procedures and assessment instruments. The result of the research shows that for the component of assessment principles, the percentage of $65.5 \%$ with moderate / moderate category, for the forms of appraisal is $62 \%$ with moderate / moderate category, while for the rating mechanism is $54.3 \%$ in moderate / moderate category, for the procedure Assessment of $42.4 \%$ with the category of less I low, and for penilain instruments of $49.3 \%$ with moderate / moderate category. From these results it is concluded that for the implementation of educational assessment standards by educators are in moderate / moderate category with a percentage of $54.7 \%$. These results do not meet the program standards that require $75 \%$. This certainly requires schools to provide training or training to educators, especially about the assessment.
\end{abstract}

Keywords: Program Evaluation, Discrepancy Evaluation Model, Educational Assessment, Educator

\begin{abstract}
ABSTRAK
Tujuan penelitian evaluasi ini adalah untuk mengetahui tingkat keberhasilan implementasi terhadap standar penilaian yang dilakukan oleh pendidik pada mata pelajaran produktif Teknik Komputer dan Jaringan (TKJ) di SMKN I Negerikaton Propinsi Lampung dengan menggunakan Model Discrepancy Evaluation Model (DEM). Metode pengumpulan data dilakukan melalui wawancara, observasi, studi dokumen dan angket. Penelitian ini difokuskan terhadap penilaian yang dilakukan oleh pendidik yang komponen prinsip-prinsip penelitian, bentuk-bentuk penilaian, mekanisme penilaian, prosedur penilaian dan instrumen penilaian. Hasil penelitian menunjukkan bahwa untuk komponen prinsip-prinsip penilaian menghasilkan persentase sebesar $65.5 \%$ dengan kategori sedang/moderat, untuk bentuk-bentuk penilaian sebesar $62 \%$ dengan kategori sedang/moderat, sedangkan untuk mekanisme penilaian sebesar $54.3 \%$ dengan kategori sedang/moderat, untuk prosedur penilaian sebesar $42.4 \%$ dengan kategori kurang/rendah, dan untuk instrumen penilain sebesar $49.3 \%$ dengan kategori sedang/moderat. Dari hasil tersebut disimpulkan bahwa untuk implementasi standar penilaian pendidikan oleh pendidik berada pada kategori sedang/moderat dengan persentase sebesar $54.7 \%$. Hasil ini belum memenuhi standar program yang mengharuskan $75 \%$. Hal ini tentunya mengharuskan sekolah untuk memberikan diklat atau pelatihan terhadap pendidik terutama tentang penilaian.
\end{abstract}

Kata kunci: Evaluasi Program, Discrepancy Evaluation Model (DEM), Penilaian Pendidikan, Pendidik

\begin{tabular}{l}
\hline Alamat \\
Korespondensi \\
Jl. Pemuda 2, No. 36, \\
Rawamangun, \\
Jakarta Timur, DKI \\
Jakarta \\
Indonesia \\
e-mail: \\
aguswahyudi0808@gmail \\
.com
\end{tabular}

\section{Pendahuluan}

Penilaian dalam pendidikan mempunyai peranan sangat penting di era modern saat ini. Menurut Djemari Mardapi (2008), penilaian merupakan komponen penting dalam penyelenggaraan pendidikan. upaya untuk meningkatkan kualitas pendidikan dapat ditempuh melalui peningkatan kualitas pembelajaran dan kualitas sistem penilaiannya. Kualitas pembelajaran dapat dilihat dari hasil penilaiannya. Sistem penilaian yang baik akan mendorong pendidik untuk menentukan strategi mengajar yang baik dan memotivasi peserta didik untuk belajar lebih baik.

Kualitas penilaian pendidikan yang dilakukan oleh pendidik berpedoman pada Peraturan Menteri Pendidikan dan Kebudayaan Nomor 23 Tahun 2016 tentang standar penilaian pendidikan. Dalam Permen tersebut disebutkan bahwa 
Agus Wahyudi

Komarudin

Awaluddin Tjalla

penilaian pendidikan oleh pendidik dilaksanakan dengan memperhatikan prinsip-prinsip penilaian, bentuk penilaian, mekanisme penilaian, prosedur penilaian dan instrumen penilaian.

Penelitian ini merupakan penelitian evaluasi yang akan menilai sejauh mana implementasi standar-standar penilaian pendidikan oleh pendidik yang mengacu pada Permendikbud Nomor 23 Tahun 2016 terutama pada pembelajaran produktif Teknik Komputer dan Jaringan di SMKN I Negerikaton Lampung.

Menurut Malcolm Provus (197I), evaluasi adalah proses sistematis untuk melihat apakah program sudah berjalan sesuai dengan standar yang ditentukan atau tidak. Titik tekan pada kesenjangan atau perbedaan adalah antara kinerja (performance) dan standar (standards) inilah yang menjadi kunci dari model ini.

Bloom Cs dalam A.Muri Yusuf (2015) menyatakan bahwa evaluasi merupakan suatu proses pengumpulan dan analisa data secara sistematis untuk mengetahui bukti penguasaan peserta didik dalam belajar, ketercapaian tujuan yang telah ditetapkan dan menentukan keefektifan pendidik dan pembelajaran. Worthen dan Sander (1973) menjelaskan bahwa evaluasi sebagai kegiatan untuk menentukan nilai atau harga tentang sesuatu, termasuk mendapatkan informasi yang bermanfaat dalam menilai keberadaan suatu program, produk, prosedur, serta alternatif strategi yang digunakan untuk mencapai tujuan yang telah ditentukan.

Sedangkan Djuju Sudjana (2006) menyebutkan bahwa evaluasi program adalah penetapan secara sistematis tentang nilai, tujuan, efektivitas atau kecocokan sesuatu sesuai dengan kriteria dan tujuan yang telah ditetapkan sebelumnya. Proses penetapan keputusan itu didasarkan pada perbandingan secara hati-hati terhadap data yang diperoleh dengan menggunakan standar tertentu yang telah dibakukan.

Undang-Undang Nomor 20 Tahun 2003 tentang Sistem Pendidikan Nasional menerangkan bahwa evaluasi dilakukan dalam rangka pengendalian mutu pendidikan secara nasional sebagai bentuk akuntabilitas penyelenggara pendidikan kepada pihak yang berkepentingan. Evaluasi dilakukan terhadap peserta didik, lembaga dan program pendidikan pada jalus pendidikan formal dan nonformal untuk jenjang, satuan dan jenis pendidikan.

Peraturan Pemerintah Nomor 19 tahun 2005 tentang Standar Nasional Pendidikan menjelaskan bahwa evaluasi pendidikan merupakan kegiatan pengendalian, penjaminan dan penetapan mutu pendidikan terhadap berbagai komponen pendidikan pada setiap jalus, jenjang dan jenis pendidikan sebagai bentuk pertanggung jawaban penyelenggara pendidikan.

Bisa penulis sebutkan bahwa evaluasi merupakan kegiatan untuk mendapatkan informasi yang bermanfaat yang dilakukan secara sistematis tentang nilai, tujuan, efektivitas atau kecocokan sesuatu sesuai dengan kriteria dan tujuan yang telah ditetapkan sebelumnya dan digunakan sebagai bahan perbaikan suatu program.

Tujuan dari penelitian evaluasi ini adalah untuk mengetahui pencapaian tujuan program implementasi penilaian pendidikan yang dilaksanakan oleh pendidik berdasarkan informasi dan data yang diperoleh di lapangan.

\section{Metode Penelitian}

Penelitian ini menggunakan Model Discrepancy Evaluation Model (DEM) yang dikembangkan oleh Malcolm Provus (197I). Evaluasi model ini merupakan salah satu model evaluasi yang berbasis pada tujuan (objective oriented evaluation model) yang artinya menuntut dirumuskannya tujuan-tujuan spesifik program secara jelas karena penilaian menitikberatkan pada ketercapaian tujuan program.

DEM bertumpu pada 4 (empat) tahap : I) Definition stage (tahap definisi), yaitu tahap untuk menentukan tujuan, proses/aktivitas, sumber daya, dan lain sebagainya, 2) Installation stage (tahap instalasi/ pemasangan), yaitu tahap untuk mengidentifikasi perbedaan pelaksanaan program dengan standar yang ditentukan, 3) Process stage (tahap proses), yaitu tahap untuk menentukan 
Agus Wahyudi

Komarudin

Awaluddin Tjalla

tingkat pencapaian tujuan jangka pendek atau "tujuan yang memungkinkan telah dicapai", 4) Product stage (tahap produk), yaitu tahap untuk melihat pencapaian tujuan "terminal" atau tujuan akhir program. Hal ini selaras dengan yang disampaikan oleh Marvin Alkin dan Cristina sebagai berikut :

The four primary stages are definition (intended to specify the goals, processes, resources, etc.); installation (to identify discrepancies in the implementation of the program); process (to determine the extent of attainment of short-term outcomes or "enabling objectives"); and product (the extent of attainment of terminal or ultimate objectives. The fifth (optional) stage is cost-benefit analysis. One particular feature of Discrepancy Evaluation is its unique emphasis on program design (the design stage).

Namun Provus seperti yang dikutip oleh Nyre dan Rose menilai DEM sebagai sebuah proses: I) mendefinisikan standar program; 2) menentukan apakah ada ketidaksesuaian antara beberapa aspek kinerja program dan standar yang mengatur aspek dari program; dan 3) menggunakan informasi ketidaksesuaian yang diperoleh, baik untuk mengubah kinerja atau untuk mengubah standar program. Hal ini dijelaskan sebagai berikut:

...the process of I) defining program standards; 2) determining whether a discrepancy exists between some aspect of program performance and the standards governing that aspect of the program; and 3) using discrepancy information either to change performance or to change program standards

Berdasarkan paparan di atas dapat diketahui, bahwa DEM yang dikembangkan Provus digunakan untuk mengetahui tingkat kesesuaian atau kesenjangan antara standar (standard) yang sudah ditentukan dalam program dengan kinerja (performance) yang sesungguhnya dari program tersebut. Pendekatan ini menggunakan langkah-langkah atau tahapan: I) disain, 2) instalasi, 3) proses, 4) produk, dan 5) analisis biaya-manfaat (optional). Namun dalam penelitian ini hanya mengimplementasikan 4 (empat) tahapan untuk untuk menilai tingkat kesesuaian atau kesenjangan antara standar program dengan kinerja sesungguhnya di SMKN I Negerikaton Lampung 
Agus Wahyudi

Komarudin

Awaluddin Tjalla
Evaluasi Implementasi Penilaian Pendidikan Oleh Pendidik Pada Mata

Pelajaran Produktif TKJ di SMKN I Negerikaton - Lampung (Menggunakan Discrepancy Evaluation Model/DEM)

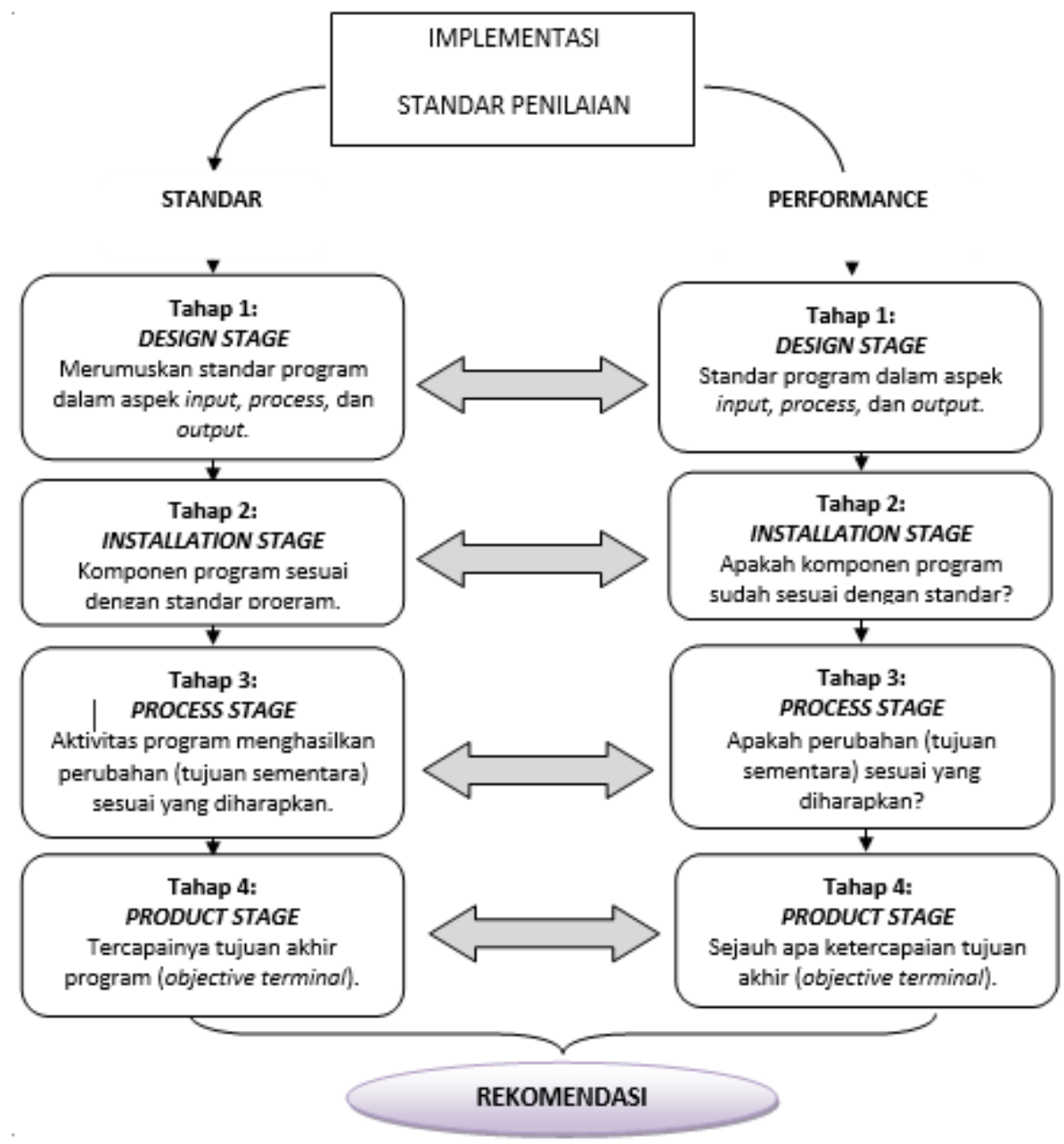

Gambar ITahapan Umum Model Iluminatif

\section{Hasil Penelitian dan Pembahasan}

Dari hasil evaluasi dilapangan diketahui bahwa untuk tahap Design Program sebagai berikut :

\begin{tabular}{|c|l|c|}
\hline Aspek & Kondisi Standar & $\begin{array}{c}\text { Kondisi } \\
\text { Aktual }\end{array}$ \\
\hline \multirow{3}{*}{ Input } & $\begin{array}{l}\text { Standar Penilaian } \\
\text { pendidikan }\end{array}$ & Tersedia \\
\cline { 2 - 3 } & Kompetensi Pendidik & Tersedia \\
\cline { 2 - 3 } & Peserta Didik & Tersedia \\
\cline { 2 - 3 } & Pengelolaan & Tersedia \\
\cline { 2 - 3 } & Struktur Kurikulum & Tersedia \\
\cline { 2 - 3 } & Sarana dan Prasarana & Tersedia \\
\hline Process & $\begin{array}{l}\text { Kegiatan } \\
\text { Pembelajaran }\end{array}$ \\
\hline
\end{tabular}

\begin{tabular}{|c|l|c|}
\hline & Pengelolaan Penilaian & Tersedia \\
\cline { 2 - 3 } & $\begin{array}{l}\text { Pelaksanaan } \\
\text { Kurikulum }\end{array}$ & Tersedia \\
\cline { 2 - 3 } & $\begin{array}{l}\text { Pengawasan } \\
\text { Pembelajaran }\end{array}$ & Tersedia \\
\hline Output & $\begin{array}{l}\text { Hasil penilaian peserta } \\
\text { didik yang mencakup } \\
\text { aspek kognitif, afektif } \\
\text { dan psikomotorik }\end{array}$ & Tersedia \\
\hline
\end{tabular}


Agus Wahyudi

Komarudin

Awaluddin Tjalla
Evaluasi Implementasi Penilaian Pendidikan Oleh Pendidik Pada Mata

Pelajaran Produktif TKJ di SMKN I Negerikaton - Lampung

(Menggunakan Discrepancy Evaluation Model/DEM)

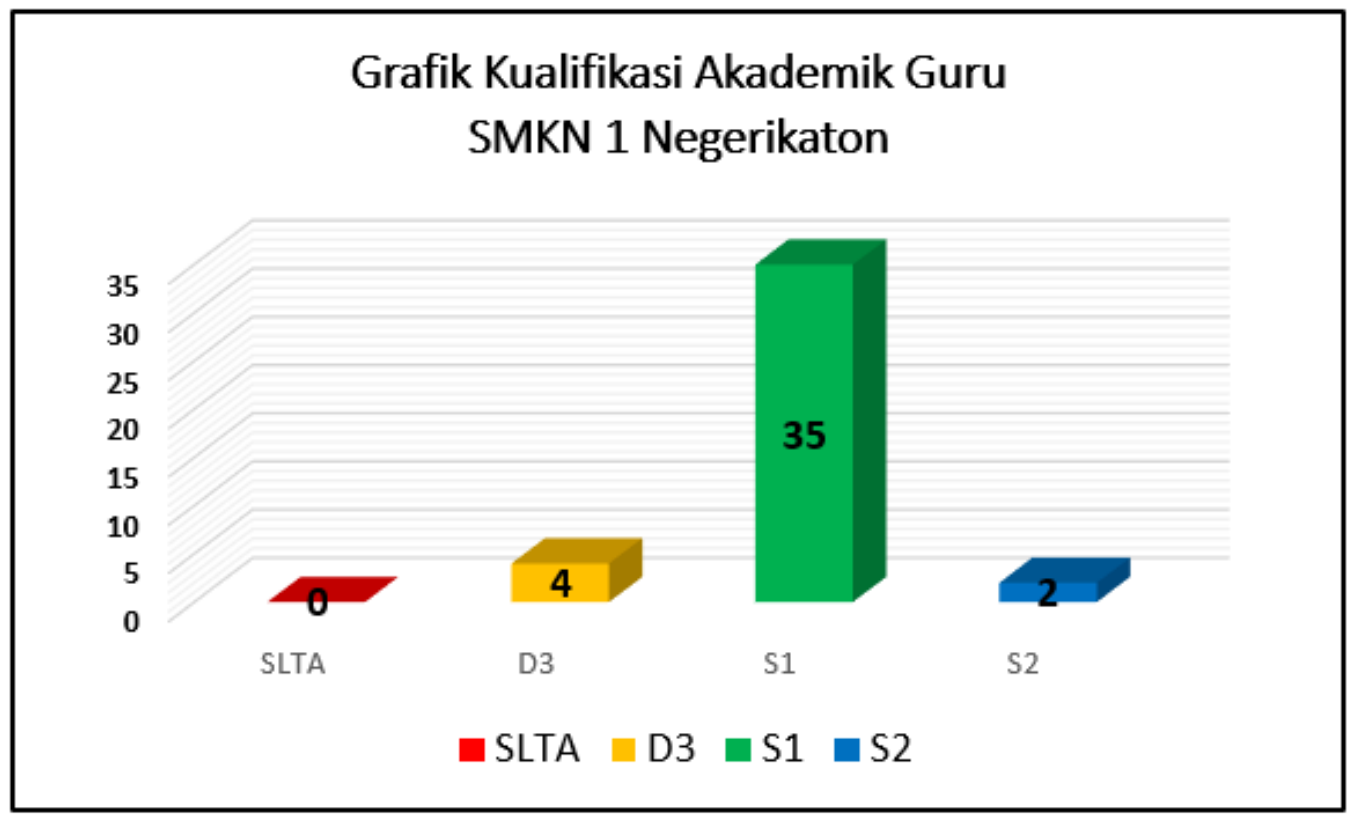

\section{Grafik 4.1 Kualifikasi Akademik Pendidik}

Sedangkan untuk kompetensi pendidik terhadap standar penilaian pendidikan oleh pendidik dapat dilihat dari tabel berikut :

Tabel 2. Kompetensi Pendidik terhadap implementasi penilaian pendidikan oleh pendidik

\begin{tabular}{|l|l|r|r|r|c|}
\hline No & Aspek yang dievaluasi & $\Sigma$ & $\mu$ & $\%$ & Kesimpulan \\
\hline 1 & Prinsip-prinsip Penilaian & 426 & 42,6 & 65,5 & Sedang/Moderat \\
\hline 2 & Bentuk-bentuk penilaian & 124 & 12,4 & 62,0 & Sedang/Moderat \\
\hline 3 & Mekanisme penilaian & 353 & 35,3 & 54,3 & Sedang/Moderat \\
\hline 4 & Prosedur penilaian & 382 & 38,2 & 42,4 & Kurang/Rendah \\
\hline 5 & Instrumen penilaian & 197 & 19,7 & 49,3 & Sedang/Moderat \\
\hline \multicolumn{2}{|c|}{ Jumlah } & 1482 & 148,2 & 273,5 & \multirow{2}{*}{ Sedang/Moderat } \\
\hline \multicolumn{2}{c|}{ Total } & & 29,6 & 54,7 & \\
\hline
\end{tabular}

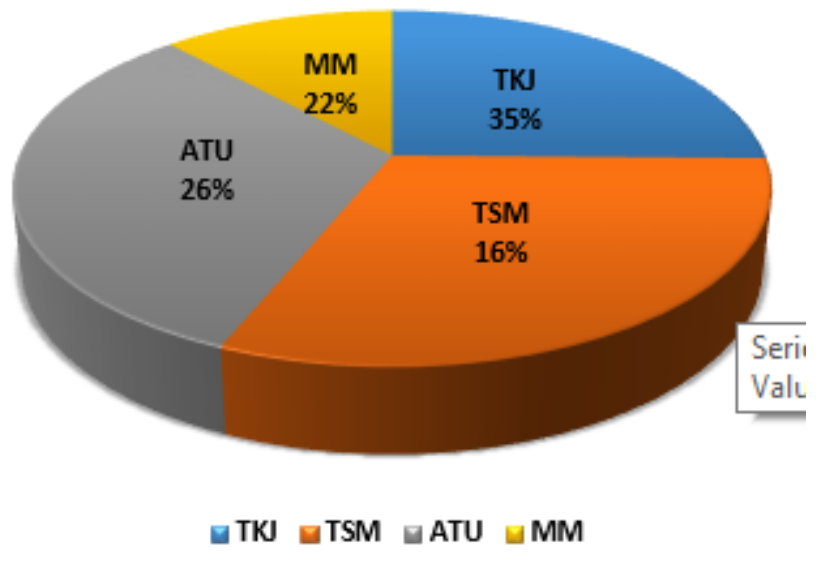

Dari tabel diatas disebutkan bahwa kompetansi pendidik terhadap implementasi penilaian pendidikan berada pada kategori sedang/moderat.

Untuk komponen peserta didik, hasil evaluasi ditunjukkan dari grafik berikut : 
Grafik 2. Persentasi Peserta Didik Setiap Program Studi

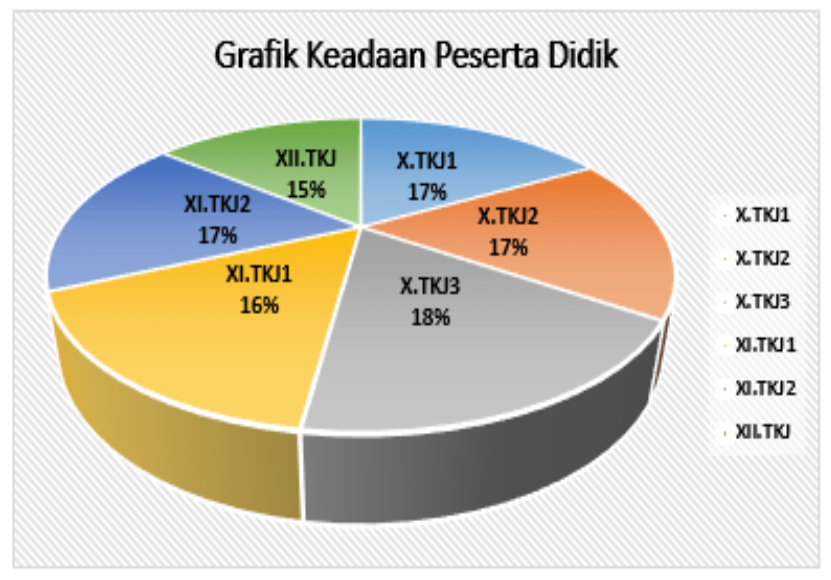

Grafik 3 : Kondisi peserta didik Program studi TKJ

Dari grafik diatas ditarik kesimpulan untuk komponen peserta didik berada pada kategori baik/tinggi dan sudah sesuai dengan standar program.

Untuk komponen kurikulum, dikelompokkan dalam kategori baik/tinggi. Sedangkan untuk komponen pengelolaan secara keseluruhan disimpulkan berada pada kategori kurang/rendah dan belum memenuhi standar program yang telah ditetapkan.

Untuk komponen sarana dan prasarana secara keseluruhan berada pada kategori baik/tinggi.

Sedangkan pada tahap Process menjelaskan komponen kegiatan pembelajaran dan penilaian pendidikan. Pada kegiatan pembelajaran diperoleh persentase sebesar $57.0 \%$ dengan kategori sedang/moderat sehingga belum memenuhi standar program.
Tabel 3. Analisis Data Proses Pembelajaran

\begin{tabular}{|c|c|c|c|c|c|}
\hline No & Aspek Yang Dievaluasi & $\Sigma$ & $\mu$ & $\%$ & Kesimpulan \\
\hline 1 & Kualitas rumusan tujuan pembelajaran. & 27 & 2,7 & 54,0 & Sedang/Moderat \\
\hline 2 & $\begin{array}{l}\text { Menyampaikan rencana dan tujuan } \\
\text { penilaian. }\end{array}$ & 26 & 2,6 & 52,0 & Sedang/Moderat \\
\hline 3 & $\begin{array}{l}\text { Memberikan motivasi kepada peserta } \\
\text { didik. }\end{array}$ & 23 & 2,3 & 46,0 & Kurang /Rendah \\
\hline 4 & $\begin{array}{l}\text { Memberikan tes pada akhir pelajaran } \\
\text { baik secara tertulis maupun lisan. }\end{array}$ & 29 & 2,9 & 58,0 & Sedang/Moderat \\
\hline 5 & $\begin{array}{l}\text { Menyampaikan kriteria ketuntasan yang } \\
\text { akan dicapai oleh pseserta didik. }\end{array}$ & 31 & 3,1 & 62,0 & Sedang/Moderat \\
\hline 6 & $\begin{array}{l}\text { Membahas tugas kepada peserta didik } \\
\text { diakhir pembelajaran. }\end{array}$ & 33 & 3,3 & 66,0 & Sedang/Moderat \\
\hline 7 & $\begin{array}{l}\text { Teknik penilaian yang digunakan pada } \\
\text { setiap penilaian berbeda sesuai dengan } \\
\text { kompetensi yang diberikan kepada } \\
\text { peserta didik. }\end{array}$ & 31 & 3,1 & 62,0 & Sedang/Moderat \\
\hline 8 & $\begin{array}{l}\text { Menyampaikan hasil penilaian kepada } \\
\text { peserta didik. }\end{array}$ & 27 & 2,7 & 54,0 & Sedang/Moderat \\
\hline 9 & $\begin{array}{l}\text { Membuat rekap penilaian dari hasil } \\
\text { penilaian yang telah dilakukan }\end{array}$ & 29 & 2,9 & 58,0 & Sedang/Moderat \\
\hline 10 & $\begin{array}{l}\text { Melakukakan evaluasi terhadap penilaian } \\
\text { yang telah dilakukan }\end{array}$ & 29 & 2,9 & 58,0 & Sedang/Moderat \\
\hline & Jumlah & 285 & 28,5 & 570,0 & \multirow{2}{*}{ Sedang/Moderat } \\
\hline & Total & & 2,85 & 57,0 & \\
\hline
\end{tabular}

Sedangkan untuk komponen penilaian pendidikan diperoleh persentase sebesar $53.1 \%$ dengan kategori sedang/moderat.

Untuk tahap produk, terdiri dari aspek kognitif, afektif dan psikomotorik. Dari penelitian yang telah dilakukan, dijelaskan bahwa untuk aspek kognitif berada pada kategori sedang/moderat dengan persentase sebesar $60 \%$. Walaupun semua peserta didik setiap tahunnya naik kelas dan lulus, tapi ada beberapa instrumen yang memiliki nilai di bawah standar program.

Sedangkan untuk aspek afektif masih berada pada kategori kurang/rendah dengan persentase sebesar 10\% saja. Dan untuk aspek psikomotorik berada pada kategori baik/tinggi.

Dengan demikian secara keseluruhan dapat disimpulkan bahwa untuk tahap produk program belum sesuai dengan standar program yang mengharuskan semua aspek penilaian berada pada kategori baik/tinggi. 


\begin{tabular}{|c|c|c|c|c|}
\hline Tahap & Komponen & Standar Program & Kondisi Aktual & Kesimpulan \\
\hline \multirow{3}{*}{ 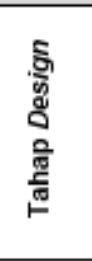 } & $\begin{array}{l}\text { Tersedianya } \\
\text { komponen input }\end{array}$ & $\begin{array}{l}\text { Tersedianya standar penilaian } \\
\text { pendidikan, pendidik, peserta didik, } \\
\text { pengelolaan, kurikulum dan sarana } \\
\text { prasarana }\end{array}$ & $\begin{array}{l}\text { Tersedianya standar penilaian } \\
\text { pendidikan, pendidik, peserta didik, } \\
\text { pengelolaan, kurikulum dan sarana } \\
\text { prasarana }\end{array}$ & $\begin{array}{l}\text { Tercapai dan sesuai } \\
\text { dengan standar }\end{array}$ \\
\hline & $\begin{array}{l}\text { Tersedianya } \\
\text { komponen process }\end{array}$ & $\begin{array}{l}\text { Tersedianya kegiatan pembelajaran } \\
\text { dan kegiatan penilaian }\end{array}$ & $\begin{array}{l}\text { Tersedianya kegiatan pembelajaran } \\
\text { dan kegiatan penilaian }\end{array}$ & $\begin{array}{l}\text { Tercapai dan sesuai } \\
\text { dengan standar }\end{array}$ \\
\hline & $\begin{array}{l}\text { Tersedianya } \\
\text { komponen output }\end{array}$ & Tersedianya tujuan penilaian & Tersedianya tujuan penilaian & $\begin{array}{l}\text { Tercapai dan sesuai } \\
\text { dengan standar }\end{array}$ \\
\hline \multirow{8}{*}{ 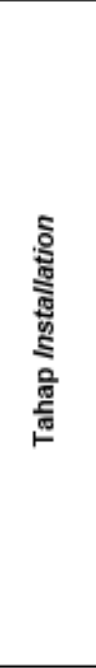 } & Standar Penilaian & $\begin{array}{l}\text { Standar penilaian mencakup } \\
\text { prinsip-prinsip penilaian, bentuk } \\
\text { penilaian, mekanisme penilaian, } \\
\text { prosedur penilaian dan instrumen } \\
\text { penilaian. }\end{array}$ & $\begin{array}{l}\text { Tersedianya Sta Chart Area } \\
\text { mencakup prinsip-prmsip permaian, } \\
\text { bentuk penilaian, mekanisme } \\
\text { penilaian, prosedur penilaian dan } \\
\text { instrumen penilaian. }\end{array}$ & $\begin{array}{l}\text { Tercapai dan sesuai } \\
\text { dengan standar }\end{array}$ \\
\hline & Pendidik & $\begin{array}{l}100 \% \text { kualifikasi pendidik minimal } \\
\text { S1 }\end{array}$ & $\begin{array}{l}50 \% \text { pendidik memiliki kualifikasi S1 } \\
\text { dan } 10 \% \text { memiliki kualifikasi S.2 }\end{array}$ & $\begin{array}{l}\text { Belum tercapai dan perlu } \\
\text { ditingkatkan }\end{array}$ \\
\hline & & $\begin{array}{l}\text { Kompetensi pendidik terhadap } \\
\text { penilaian pendidikan }\end{array}$ & $\begin{array}{l}54 \% \text { pendidik memiliki kompensi } \\
\text { terhadap penilaian pendidikan }\end{array}$ & $\begin{array}{l}\text { Belum tercapai dan perlu } \\
\text { ditingkatkan }\end{array}$ \\
\hline & Peserta Didik & Minat dan bakat peserta didik & $\begin{array}{l}\text { Minat dan bakat peserta didik untuk } \\
\text { masuk ke prodi TKJ baik/tinggi }\end{array}$ & $\begin{array}{l}\text { Tercapai dan sesuai } \\
\text { dengan standar }\end{array}$ \\
\hline & Kurikulum & $\begin{array}{l}\text { Struktur kurikulum sesuai dengan } \\
\text { peraturan pemerintah }\end{array}$ & $\begin{array}{l}\text { Struktur kurikulum sesuai dengan } \\
\text { peraturan dari pemerintah }\end{array}$ & $\begin{array}{l}\text { Tercapai dan sesuai } \\
\text { dengan standar }\end{array}$ \\
\hline & Pengelolaan & $\begin{array}{l}\text { Pengelolaan penilaian sesuai } \\
\text { dengan standar program }\end{array}$ & $\begin{array}{l}\text { Rata-rata persentase pengelolaan } \\
\text { penilaian hanya } 47,8 \% \text { dan masih } \\
\text { belum sesuai dengan standar } \\
\text { program }\end{array}$ & $\begin{array}{l}\text { Belum tercapai dan perlu } \\
\text { ditingkatkan }\end{array}$ \\
\hline & $\begin{array}{l}\text { Sarana dan } \\
\text { Prasarana }\end{array}$ & $\begin{array}{l}\text { Prasarana memadai sesuai dengan } \\
\text { peraturan tentang standar sarpras }\end{array}$ & $\begin{array}{l}\text { Tersedianya Prasarana yang } \\
\text { memadai }\end{array}$ & $\begin{array}{l}\text { Tercapai dan sesuai } \\
\text { dengan standar }\end{array}$ \\
\hline & & $\begin{array}{l}\text { Sarana memadai sesuai dengan } \\
\text { peraturan tentang standar sarpras }\end{array}$ & Tersedianya sarana yang memadai & $\begin{array}{l}\text { Tercapai dan sesuai } \\
\text { dengan standar }\end{array}$ \\
\hline
\end{tabular}

\begin{tabular}{|c|c|c|c|c|}
\hline Tahap & Komponen & Standar Program & Kondisi Aktual & Kesimpulan \\
\hline \multirow{2}{*}{$\begin{array}{c}\text { Tahap } \\
\text { Process }\end{array}$} & Pembelajaran & Pembelajaran berjalan dengan baik & $\begin{array}{l}\text { Hanya } 57 \% \text { pendidik menerapkan } \\
\text { pembelajaran dengan baik }\end{array}$ & $\begin{array}{l}\text { Belum tercapai dan perlu } \\
\text { ditingkatkan }\end{array}$ \\
\hline & Penilaian & $\begin{array}{l}\text { Proses penilaian sesuai dengan } \\
\text { standar program }\end{array}$ & $\begin{array}{l}\text { Hanya } 53 \% \text { pendidik melakuak } \\
\text { proses penilaian dengan baik }\end{array}$ & $\begin{array}{l}\text { Belum tercapai dan perlu } \\
\text { ditingkatkan }\end{array}$ \\
\hline \multirow{3}{*}{ 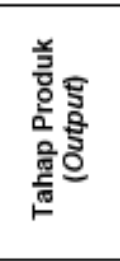 } & Aspek Kognitif & $\begin{array}{l}\text { Nilai rata-rata kognitif mata } \\
\text { pelajaran produktif sesuai dengan } \\
\text { standar }\end{array}$ & Tersedianya nilai rata-rata kognitif & $\begin{array}{l}\text { Tercapai dan sesuai } \\
\text { dengan standar }\end{array}$ \\
\hline & Aspek Afektif & Tersedianya Laporan nilai afektif & Belum tersedianya nilai afektif & $\begin{array}{l}\text { Belum tercapai dan perlu } \\
\text { ditingkatkan }\end{array}$ \\
\hline & Aspek Psikomotorik & \multicolumn{2}{|c|}{$\begin{array}{l}\text { Rata-rata nilai psikomoto Chart Area ersedianya nilai rata-rata } \\
\text { pelajaran produktif sesuar dengan } \\
\text { standar }\end{array}$} & $\begin{array}{l}\text { Tercapai dan sesuai } \\
\text { dengan standar }\end{array}$ \\
\hline
\end{tabular}

Tabel 4 Perbandingan kondisi aktual dengan standar program

\section{Kesimpulan}

Berdasarkan hasil evaluasi yang sudah dijelaskan, maka Implementasi Penilaian Pendidikan oleh Pendidik pada mata pelajaran produktif TKJ di SMKN I Negerikaton dapat didimpulkan sebagai berikut :

I. Pada tahap Design untuk aspek input, process dan output sudah tersedia dan sesuai dengan standar sehingga pada tahap design dinyatakan sudah sesuai dengan standar program.

2. Pada tahap Installation komponen standar penilaian, peserta didik, kurikulum, sarana dan

\section{Daftar Pustaka}

prasarana sudah tercapai dan sesuai dengan standar. Sedangkan untuk komponen pendidik dan pengelolaan belum mencapai standar program dan masih perlu ditingkatkan.

3. Pada tahap Process, komponen pembelajaran dan penilaian belum mencapai standar program dan masih perlu ditingkatkan.

4. Untuk tapap produk (output), aspek kognitif dan psikomotorik sudah mencapai standar, sedangkan untuk aspek afektif masih perlu ditingkatkan.

A. Muri Yusuf. Asesmen dan Evaluasi Pendidikan. Jakarta : Prenadamedia, 2015. 
Agus Wahyudi

Komarudin

Awaluddin Tjalla

Djaali dan Pudji Mulyono, Pengukuran dalam Bidang Pendidikan. Jakarta: PT. Grasindo, 2008.

Djemari Mardapi. Teknis Penyusunan Instrumen Tes \& Nontes. Yogyakarta : Mitra Cendekia Press, 2008.

Glenn F. Nyre dan Clare Rose, "The Practice of Evaluation. University of Nebraska Lincoln: The Journal of the Professional and Organization Development Network in Higher Education, I0-I-I979, http//digitalcommons.unl.edu/podqtrly/20. diakses, I 3 Januari 2012.

Marvin C. Alkin and Cristina A. Christie, "An Evaluation Theory Tree," http//.sagepub.comupmdata5074_Alkin_Chapter_2.pdf. diakses 15 Desember 2016
Peraturan Pemerintah Nomor 19 Tahun 2005 tentang Standar Nasional Pendidikan, Pasal I ayat 18.

Peraturan Menteri Pendidikan Nasional Republik Indonesia Nomor 20 Tahun 2007 tentang Standar Penilaian Pendidikan.

Permendikbud Nomor 66 Tahun 2013 tentang Standar Penilaian

Provus, M.M. The Discrepancy Evaluation Model an Approach to Local Program Improvement and Development. Washington, D.C. : Pittsburgh Public Schools, Pa, 1969.

Undang-Undang Nomor 20 Tahun 2003 tentang Sistem Pendidikan Nasional. 